In press, Personality and Social Psychology Bulletin

\title{
Am I a Science Person? A Strong Science Identity Bolsters Minority Students' Sense of Belonging and Performance in College
}

\author{
Susie Chen ${ }^{1}$, Kevin R. Binning ${ }^{1}$, Kody J. Manke ${ }^{2}$, Shannon T. Brady ${ }^{3}$, Erica M. McGreevy ${ }^{4}$, \\ Laura Betancur ${ }^{1}$, Lisa B. Limeri ${ }^{5}$, and Nancy Kaufmann ${ }^{4}$ \\ ${ }^{1}$ University of Pittsburgh, Department of Psychology \\ ${ }^{2}$ Carnegie Mellon University, Department of Psychology \\ ${ }^{3}$ Wake Forest University, Department of Psychology \\ ${ }^{4}$ University of Pittsburgh, Department of Biological Sciences \\ ${ }^{5}$ University of Georgia, Department of Biochemistry and Molecular Biology
}

In press, June 2, 2020

This work was supported by funding from NSF-DUE \#1524575 


\begin{abstract}
Identifying as a "science person" is predictive of science success, but the mechanisms involved are not well-understood. We hypothesized that science identity predicts success because it fosters a sense of belonging in science classrooms. Thus, science identity should be particularly important for first-generation and racial-minority students, who may harbor doubts about belonging in science. Two field studies in college Introductory Biology classes $(N s=368 ; 639)$ supported these hypotheses. A strong science identity predicted higher grades, particularly for minority students. Also consistent with hypotheses, Study 2 found that self-reported belonging in college mediated the relationship between science identity and performance. Furthermore, a social belonging manipulation eliminated the relationship between science identity and performance among minority students. These results support the idea that a strong science identity is particularly beneficial for minority students because it bolsters belonging in science courses.
\end{abstract}

Keywords: science identity, belonging, minority, threat, performance 


\section{Am I a Science Person? A Strong Science Identity Bolsters Minority Students' Sense of Belonging and Performance in College}

The number of students in the United States receiving bachelor's degrees in science, technology, engineering, and mathematics (STEM) fields has steadily risen over time, increasing 20 percent from 2009 to 2014 (NCES, 2014). However, substantial group-based disparities persist in who earns these degrees. For instance, though STEM degree attainment increased for all students over this time period, the increase for White students was three times greater than for Black and Hispanic students over the same time. Additionally, students whose parents do not have a 4-year degree (i.e., first-generation college students) earn lower grades and drop out of college more frequently than students with at least one parent with a 4-year degree (Sirin, 2005).

The current studies argue that these disparities exist partly because many racial/ethnicminoritized students and first-generation college students—whom we refer to as minority students for the purposes of this paper—come to see themselves as not belonging in STEM. Reasons for why this occurs are multifaceted, including macro-level forces (e.g., structural inequalities) that feed into micro-level psychological experiences (e.g., anxiety during intergroup interactions). These forces work together to produce cultural stereotypes and lay beliefs about who belongs and succeeds in science, with White individual—and White males in particularseen as the most prototypical, normative STEM group members. For students seen as peripheral and non-prototypical, factors like belonging uncertainty (Walton \& Cohen, 2007) and stereotype threat (Steele, 1997) hinder academic performance and perpetuate achievement gaps which reinforce STEM inequalities (see Binning \& Browman, 2020).

In the present research, we examine one individual difference that may mitigate the cycle of inequality and underperformance: a strong science identity (science ID). Identifying with the 
science domain - when being a "science person" is seen as important to the self-concept - may buffer against the forces that conspire to make students, especially minority students, perform below their potential in STEM. Below, we review the science ID literature and its relationship to performance and belonging for minority and majority college students. We then present two studies that tested the impact of science ID on college performance in an important gateway science course, Introductory Biology.

\section{Science Identity and Performance in Science Fields}

Definitions of science ID emphasize both private and public identification with the science domain (Gee, 2000; Vincent-Ruz \& Schunn, 2018). That is, a student has a strong science ID when both the student themselves and their important social reference groups (e.g., friends, family) perceive the student as a "science person." Fostering a positive science ID is a goal of many educational programs, including those found in science museums (Leinhardt, Crowley, \& Knutson, 2011), children's television (e.g., Sci-Girls; Dawson, 2014), formal science curriculums (Falk \& Needham, 2011; Hulleman \& Harackiewicz, 2009), and educational interventions (Ramsey, Betz, \& Sekaquaptewa, 2013).

Several studies have found that students who identify with science are more likely to persist and perform well in science fields (Eccles \& Barber, 1999; Osborne \& Walker, 2006). In one survey of more than 600 science-oriented undergraduate and graduate students, Chemers and colleagues (2011) found students' level of identification as a scientist was predictive of their commitment to a science career. This effect also occurs with racial/ethnic-minoritized students, as seen in a study by Chang and colleagues (2011). Surveying 1,745 underrepresented racial/ethnic-minoritized college students, they found that identification with the biomedical and behavioral sciences predicted students' persistence in those majors beyond their first year. 
Similarly, among 1,420 largely racial/ethnic-minoritized participants, Stets and colleagues (2017) found that strong science ID near the end of college was associated with entering a science career.

Studies show an analogous influence of science ID on science interest and persistence among first-generation students. For example, Verdín and Godwin (2018) found that firstgeneration college students in engineering were more likely to persist on this career trajectory if they strongly identified as an engineer early in college. This is likely to occur because the same structural factors (e.g., poverty) that affect racial/ethnic-minoritized students can also cause firstgeneration students to feel less belonging (Astin, 1993; Yeager et al., 2016) and more isolation (Pascarella, Pierson, Wolniak, \& Terenzini, 2004) in college. Studies show these factors impact academic performance, as forces like stereotype threat and belonging uncertainty affect both first-generation and racial/ethnic-minoritized students (Croizet \& Claire, 1998; Stephens, Fryberg, Markus, Johnson, \& Covarrubias, 2012).

These studies illustrate that a strong science ID is associated with better outcomes in college science courses for minority students who contend with doubts about belonging. However, one limitation of this work is that it has generally not examined differences in science ID's effect between minority and majority group members. While evidence suggests that science ID may be beneficial for academic success, it is unclear whether this is the case for all students or particularly true for minority students. Furthermore, this work has not generally sought to understand why science ID may have beneficial effects. We argue that science ID is important for all students but likely especially important for minority students who contend with doubts 
about belonging, ${ }^{1}$ as it potentially buffers them against these doubts that might otherwise undermine STEM performance and engagement.

\section{Science Identity and Belonging}

To understand the relationship between science ID and belonging, consider a situation in which a student performs unexpectedly poorly on a biology exam. Students from all backgrounds may find the experience threatening to their competence, but students from minority groups must also contend with anxiety that this performance "confirms" negative academic stereotypes attributed to their group memberships (Crocker \& Major, 1989, Steele, 1997). Thus, rather than seeing this adversity as temporary and universal (e.g., "All students occasionally struggle"), this ambiguity may lead them to attribute their adversity to their group membership (e.g., "Students like me don’t do well in science"; Croizet \& Claire, 1998; Steele \& Aronson, 1995; Walton \& Wilson, 2018). Attributing a poor outcome to internal, stable causes such as one's ethnic identity or social class can hinder engagement by making persistence in science seem futile or threatening (see Dweck, 2008; Weiner, 1985). Minority students also tend to have fewer ingroup role models, hindering their sense that "people like me" can do well in the domain (Dasgupta, 2011; Stout, Dasgupta, Hunsinger, \& McManus, 2011).

We argue that a strong science ID may serve as a psychological resource to forestall such harmful internal attributions and belonging uncertainty. Minority students may be aware that students from their group historically underperform, but possession of a strong science ID may bolster the belief that they personally still belong, making it more likely they are able to maintain engagement in the face of adversity. Functionally, a strong science ID may serve as an internal

\footnotetext{
${ }^{1}$ In many STEM domains (e.g., engineering), women also contend with stereotype threat and belonging uncertainty (Cheryan, Ziegler, Montoya, \& Jiang, 2017). However, this tends to be less prevalent in Biology, where women tend to be more equitably-represented (Leslie, Cimpian, Meyer, \& Freeland, 2015). Exploratory analyses in our studies found no significant effects of gender $(p s>.10)$. As such, gender was not the focus of the present research.
} 
rebuttal to the insinuation that the student does not belong ("That professor might think I'm not the right fit for science, but I know I am").

Thus, we argue that if science ID bolsters belonging in science in this way, it may be especially important for students who are more susceptible to doubts about belonging (Carlone, 2004; Seymour, Hewitt, \& Friend, 1997). To this point, correlational research has shown that doubts about belonging and discrimination can undermine students' likelihood of forming positive science IDs in the first place (Aschbacher, Li, \& Roth, 2010; Hazari, Sadler, \& Sonnert, 2013). In the present research, we aim to break this effect of belonging on science ID by considering science ID as a predictor variable, one that bolsters students' sense of belonging and consequently improves academic performance.

\section{Overview of Present Research}

To extend the research on the relationship between science ID and performance, we addressed the two following research questions: 1) Is science ID differentially predictive of course performance for minority (racial/ethnic-minoritized; first-generation) and majority (White; continuing-generation) group students?; and 2) Is the differential effect of science ID on performance due to science ID conferring an increased sense of belonging? Though we focus on a domain-specific identity—science ID—and thus domain-specific belonging, we argue that science belonging contributes to general school belonging (e.g., Freeman, Anderman, \& Jensen, 2007).

To address these questions, we conducted two studies that measured the science ID of college students enrolled in Introductory Biology, an important gateway course taken by first- 
year students. ${ }^{2}$ Analyses of historical data from this course found that the majority of enrolled students pursued careers in health and biology-related fields; importantly, students are required to earn at least a "C" in the course to continue in health science disciplines. The high-stakes nature and difficulty of the course, together with the fact that students tend to take the course in their first year, formed a potent combination of stressors we assumed would make having a strong science ID especially useful.

To test whether the benefits of science ID varied across groups, we created a categorization of who we expected to experience heightened belonging uncertainty in this course; as such, we compared minority students to majority students. This categorization followed from both the literature and historical course analyses; analyses of the prior three years of Introductory Biology at the university where the study was conducted indicated that racial/ethnic-minoritized students (e.g., Black, African-American, Hispanic, Latino/a, Native American/American Indian) and first-generation college students of any racial/ethnic background scored lower in the course compared to their White, continuing-generation peers. ${ }^{3}$ An important consideration we encountered was how to categorize Asian/Asian-American students, a group who traditionally faces positive academic stereotypes (see Cheryan \& Bodenhausen, 2011). The same historical analyses indicated that in Introductory Biology, these students underperformed relative to their White classmates. ${ }^{4}$ Therefore, Asian/Asian-American students were included in the minority group for analyses.

\footnotetext{
2 Though Biology differs from other STEM courses (e.g., women are often overrepresented in Biology, compared to other fields; Meyer, Cimpian, \& Leslie, 2015), it is still encompassed within the general science domain and therefore an appropriate venue for studying science ID.

${ }^{3}$ This encompassing definition of minority also increased statistical power. There were not enough first-generation students $\left(N_{\text {Study } 1}=47\right.$ and $\left.N_{\text {Study } 2}=81\right)$ to adequately analyze racial-ethnic identities and first-generation identities separately or in interaction.

${ }^{4}$ Previous work by another research team at the same university found similar underperformance for Asian//AsianAmerican students in Introductory Psychology (Betancur et al., 2018).
} 


\section{Study 1}

Study 1 focused on our first research question (RQ1), which asked whether science ID was differentially predictive of academic performance for majority and minority students. To examine this question, we used existing data from a study that was originally conducted to examine the possible effects of a values affirmation intervention (Miyake et al., 2010) but included the measures necessary to test our research question. Importantly, science ID was collected prior to the experimental manipulation of affirmation and did not interact with the manipulation; thus, the data were appropriate to examine RQ1.

\section{Method}

Participants. Participants were 368 students from two different Introductory Biology lecture sections at a large university. The majority of participants identified as women $(N=259$; $70 \%)$, and White $(N=246 ; 67 \%)$ (see Table 1 for additional demographics). All participants provided informed consent and agreed to allow access to their de-identified institutional data, accessed using an honest broker not involved in the research to maintain students' confidentiality. Instructors provided extra credit as incentive for completing the study.

Procedure. On the night before a course exam, students were emailed a Qualtrics survey which contained the science ID measure; after completing it, students were randomly assigned to see materials for either the affirmation intervention or the control condition. ${ }^{5}$ The survey was available until 10 minutes before the exam. These procedures occurred before the second exam for one course and the fourth exam for the other course.

\footnotetext{
${ }^{5}$ All participants were presented with a list of 11 values (e.g., Being with Friends or Family). Affirmation condition students were instructed to identify their most important value from the list, reflect on it, and then write a brief paragraph about a time that value was important to them. Control condition students were instructed to identify their least important value and write about why it might be important to someone else. The manipulation was patterned after those used in previous affirmation field studies (Binning et al., 2019; Sherman et al., 2013).
} 


\section{Measures}

Science Identity. Science ID was measured with 4 items (e.g., "I am a science person"; adapted from Hazari, Sonnert, Sadler, \& Shanahan, 2010). Students indicated their agreement with the items from $1=$ strongly disagree to $7=$ strongly agree. Scores were aggregated to create a single science ID variable ( $\alpha=.90, M=5.43, S D=1.20)$. In the following analyses, science ID is defined and presented as a continuous measure (students characterized having either high $(+1$ $S D)$ or low (-1 SD) science ID).

Academic Performance. The primary dependent outcome was students' course grade, calculated as a percentage out of $100(M=79.70, S D=12.38)$. Grades were obtained from the instructor.

Academic History. From the university registrar, we obtained students' ACT or SAT scores and high school GPA. Scores were transformed to Z-scores and averaged into a single composite of previous academic performance. Students with unavailable scores $(N=16)$ were assigned the mean composite score (similar to the procedure in Sherman et al., 2013).

Demographic Characteristics. University records and students' end-of-course survey responses identified students' gender, race, and parental education level. ${ }^{6}$ Students selected their racial identity from the following options (multiple selections permitted): Black or AfricanAmerican, Hispanic or Latino/a, Asian or Asian-American, White/Caucasian, Native American/American Indian, or Other. ${ }^{7}$

\section{Results}

\footnotetext{
${ }^{6}$ When demographic information from university records and student surveys conflicted $(N<30)$, we used university record information. However, using the survey data instead did not affect the findings.

${ }^{7}$ Students who selected "Other" and indicated White as one of their race components were categorized as majority students.
} 
Analytic Approach. As described, our focus and analyses specifically considered the relationship between pre-manipulation science ID and later academic outcomes; we then tested for moderation or interactions with intervention effects (which we ultimately found no evidence of). ${ }^{8}$ All analyses were conducted using the PROCESS v.2 SPSS macro (Hayes, 2012) to test for two-way and three-way interactions among condition (intervention, control), science ID (high, low), and minority status (majority, minority) on the outcome variable. We tested all effects using a non-parametric bootstrapping (5000 samples) method and controlled for gender, classroom, and the composite index of previous academic performance.

Gender and classroom covariate variables were mean-centered (Irwin \& McClelland, 2001) to improve clarity in interpreting results. Because the data was collected from two separate classes, we ran analyses to determine whether class section moderated class performance results, the main outcome of interest. Since there was no difference between classes $(t=-.87, p>.10)$, we collapsed across them for the final analyses and included dummy-codes for instructor. Table 2 presents correlations between all variables of interest.

In the analysis involving the affirmation condition, we controlled for the exam scores completed prior to distributing the affirmation intervention. ${ }^{9}$ This was done to provide the strongest possible test for affirmation: we limited the inferential tests of affirmation to performance that came after the affirmation - that is, to performance that could have plausibly been affected by the manipulation—while reducing error and controlling for any error in random assignment.

\footnotetext{
${ }^{8}$ In the spirit of transparency and completeness, we analyzed the effect of the affirmation on grade, as well as its interaction with science ID. The affirmation neither impacted grade $(B=-.05, S E=.90, t(354)=-.06, p=.624,95 \%$ $\mathrm{CI}=[-1.82,1.72]$ nor interacted with science $\mathrm{ID}(B=-.38, S E=.78, t(354)=-.49, p=.624,95 \% \mathrm{CI}=[-1.92,1.15])$. Thus, we collapsed across the experimental manipulation for Study 1 analyses.

${ }^{9}$ Similar to the analytic procedure used by Hulleman and colleagues (2017) to control for course exam scores delivered prior to a utility-values intervention.
} 


\section{RQ1: Is science ID differentially predictive of course performance for minority and}

majority group students? To address RQ1, we analyzed the main effect of science ID on course grade across all students and included all control variables. In line with previous research, science ID was significantly associated with higher performance in the class $(B=3.55, S E=.43$, $t(356)=8.27, p<.001,95 \% \mathrm{CI}=[2.71,4.40] ;$ Fig. 1$).$

There was also a significant Science ID x Minority Status interaction on course performance $(B=2.55, S E=.87, t(356)=2.94, p=.004,95 \% \mathrm{CI}=[.85,4.26]$; Fig. 1). Simple slopes analysis revealed the effect of science ID on performance was roughly two times greater for minority $(B=5.03, S E=.69, t(356)=7.43, p<.001,95 \% \mathrm{CI}=[3.68,6.38])$ than for majority students $(B=2.48, S E=.54, t(356)=4.59, p<.001,95 \% \mathrm{CI}=[1.42,3.54])$. For every 1-point increase in science ID, minority students experienced a $5 \%$ boost in grade, while majority students only saw a $2.5 \%$ boost. Thus, science ID had a greater impact on grade for minority students.

This interaction also revealed how high science ID buffered the achievement gap. For students with low science ID, results indicated a significant difference in grade between majority and minority students $(B=-4.82, S E=1.42, t(356)=-3.38, p<.001,95 \% \mathrm{CI}=[-7.62,-2.02])$, such that majority students had a 5\% higher grade than minority students. However, this gap disappeared among students with high science ID $(B=1.20, S E=1.45, t(356)=.83, p=.408$, $95 \% \mathrm{CI}=[-1.65,4.05])$.

\section{Discussion}

Study 1 addressed RQ1 regarding whether science ID had a differential benefit for minority students compared to majority students. Results revealed science ID had a larger effect for minority students, such that grade differences between low and high science ID students were 
larger among minority students than among majority students. However, results did not illuminate why this happened. As reported, analyses of the affirmation intervention revealed the intervention did not have a main effect nor interact with science ID on course performance. This was an interesting finding, given that past research has noted that affirmation interventions can elicit sense of belonging (e.g., Shnabel, Purdie-Vaughns, Cook, Garcia, \& Cohen, 2013; Tibbetts et al., 2016). It is possible that not enough students affirmed values that prompted belonging, and that perhaps a stronger belonging manipulation —as seen in Study 2-would produce the sense of belonging needed to buttress against the threat of low science ID in minority students.

Although speculative, another possibility for these null findings is that science ID, affirmation, and the various time-courses of performance in the course did not align in a way that allowed for their interaction. Past research has indicated that in regards to timing, interventions that occur in newly-formed contexts are generally more effective than when the same intervention is delivered in more established contexts (Cohen, Garcia, Purdie-Vaughns, Apfel, \& Brzustoski, 2009; Yeager \& Walton, 2011). We delivered the affirmation intervention prior to the second and fourth exam in each classroom, approximately 6 and 12 weeks into the term, respectively. If science ID does indeed protect students from stereotypes and belonging uncertainty, it may have already done so by the time the affirmation was administered.

Thus, in Study 1, we found evidence in support of our hypothesis that science ID was more predictive of subsequent academic success for minority students than for majority students. However, the study did not address our second research question (RQ2), which asks about mechanisms involved; Study 2 attempted to address this question by investigating whether belonging served as the mechanism driving the effect of science ID on academic performance.

\section{Study 2}


In Study 2, we sought to replicate and bolster the Study 1 findings for RQ1 that science ID predicts performance, and that it does so more strongly for minority than for majority students. We also aimed to address RQ2 by investigating whether belonging mediated this relationship. We theorized that science ID should foster a sense of belonging in science classes and thus the university more generally. Since science is a core mission of most research universities (like the one under study), science belonging is likely central to general university belonging. We operationalized belonging in two ways: first, by manipulating belonging with a classroom-based belonging procedure conducted in student groups (i.e., manipulate-the-mediator approach; MacKinnon \& Pirlott, 2015) and second, by measuring self-reported belonging at the university more generally (i.e., measure-the-mediator approach; Baron \& Kenny, 1986).

Manipulating social belonging. By employing a belonging manipulation, we manipulate the mediator to test belonging as a psychological process explaining the effect of science ID on performance. We hypothesized that if science ID operates through fostering a sense of belonging, then increasing belonging via an experimental manipulation carried out inside the science course may serve to mimic the positive effects of having a strong science ID, rendering science ID less predictive. The effect of science ID would be reduced analogously to the reduction in the $\mathrm{C}$ path in the Baron and Kenny (1986) measurement-based approach to mediation.

We manipulated belonging by delivering a social belonging intervention, which has been shown to mitigate negative academic outcomes for students subject to negative academic stereotypes (Walton \& Brady, 2020; Walton \& Cohen, 2011; Wilson \& Linville, 1982). This intervention focuses on teaching students to view adversity and setbacks in college as normal and temporary, not due to internal characteristics suggested by common stereotypes. That is, it seeks 
to shape the meaning students make about adversity in ways to establish and insulate sense of belonging. We theorize that having a strong science ID produces similar psychological outcomes. Students with high science ID may already feel increased sense of belonging in science, as their high identification confers a sense of competence in the domain, enabling them to engage in social connectedness with science peers, teachers, and activities. Those with low science ID, however, do not have this resource to insulate belonging. Thus, we posit that a classroom-based social belonging intervention during the first week of the semester, focused on general sense of belonging, may help such students stay engaged in the face of adversities and challenges in pursuing a science education.

Measuring Social Belonging. Following the more typical mediation approach (Baron \& Kenny, 1986), we also measured students' sense of belonging in college. We theorized that, particularly in the control condition, this measure of belonging should mediate the effect of science ID on performance. Though we measured general college belonging, we posit that this belonging could also potentially affect domain-specific science belonging (e.g., Freeman et al., 2007). That is, science ID should bolster general university belonging and in turn predict higher performance within the science classroom.

\section{Method}

Participants. The social belonging intervention and control materials were given to 639 students in an Introductory Biology course with the same instructor over two different semesters. Students were evenly-split among four recitation sections each semester, with the course instructor teaching each recitation. The final sample included 572 participants who completed the survey distributed at the end of the course. Participants were 18 years and older and largely identified as White $(N=432)$ and women $(N=429)$. See Table 1 for student demographics. 
Procedure. In each semester, we randomly assigned recitation sections to the control or belonging intervention condition (two control and two social intervention sections each semester - a total four sections per condition). In the first recitation meeting of the semester, the instructor asked students to form groups of 3-5 people based on a superficial similarity (e.g., living in the same dorm). Group members introduced themselves to each other and created a team name; students remained with this team throughout the semester. Students then completed either the belonging intervention or control condition exercise. At the end of the semester, students completed a Qualtrics survey that measured the dependent variables and demographic information. Course grades were also collected then. The timing of the science ID measure, however, differed by term. In the first semester, it was collected at the beginning of the semester via a Qualtrics survey distributed by the instructor. In the second semester, it was collected with the belonging and demographic measures at the end of the semester. ${ }^{10}$ Students received extra credit in the course for participating.

Social Belonging Intervention. The social belonging intervention was modeled after the intervention conducted by Walton and Cohen (2007; 2011), with several modifications. Most notably, random assignment was conducted at the section rather than the individual level, and the intervention was delivered within collaborative learning groups (e.g., students' science peers) inside the classroom rather than in a lab setting (see Binning et al., 2020).

The intervention focused on belonging in the university following the transition to college. To start, the instructor introduced the idea that the college transition is particularly tough, and students might be experiencing some difficulties. Students then wrote for 10 minutes about difficulties they were experiencing in their first week. After collecting and scanning the

\footnotetext{
${ }^{10}$ Since science ID was measured at different times, we first ran separate analyses for each semester. Results indicated that term did not significantly moderate the effect of science ID on course grade $(t \mathrm{~s}<2.00, p \mathrm{~s}>.50)$.
} 
writing samples, the instructor presented three quotes from junior and senior students that addressed common concerns (similar to Walton \& Cohen, 2011), many of which appeared in students' writing. These quotes reinforced a general message: difficulties in the college transition are common across students rather than indicative of a personal deficit, often temporary, and not a permanent impediment to success and belonging at the university.

This was followed by a team discussion where students discussed similarities and differences between their experiences and the situations presented in the quotes. This portion of the intervention was intended to help establish the belonging message as a shared reality or "common ground" so that students would not only adopt the message, they would know others had adopted the message, too (Binning et al., 2020; Binning \& Sherman, 2011). Finally, students were invited by the instructor to share topics brought up in group discussion with the class.

Control condition. Students in the control condition completed business-as-usual activities, which included "ice-breaker" activities of choosing a biology-themed team name, drawing a mascot, and presenting their name and mascot to the class.

\section{Measures}

Dependent and demographic measures were similar to those in Study 1, with a similar science ID measure and additional belonging measure.

Science Identity. Science ID was measured with 4 items (e.g., "I am a science person"), ${ }^{11}$ and students indicated agreement from $1=$ strongly disagree to $4=$ strongly agree. Scores were aggregated to create a single science ID variable $(\alpha=.94, M=2.98, S D=.76)$.

Belonging. Sense of belonging was assessed with a 4-item measure (e.g., "I feel like I belong at [school]"; adapted from Walton \& Cohen, 2007). Students rated their agreement with

\footnotetext{
${ }^{11}$ Though the Study 1 and Study 2 science ID measures differed in scales used, they contained the same 4 items. Study 1 analyses were conducted after launching Study 2; as such, we were unable to use the same scale.
} 
the items from $1=$ strongly disagree to $6=$ strongly agree. Items were averaged to create a composite measure of belonging $(\alpha=.87, M=4.94, S D=.85)$.

\section{Results}

As in Study 1, all analyses controlled for semester, gender, and previous academic performance. Because similar patterns emerged between the two semesters, we collapsed data across semesters; all analyses were conducted based off all available data. ${ }^{12}$ Table 3 presents correlations between all variables of interest.

\section{RQ1: Is science ID differentially predictive of performance for minority and} majority group students? We found a significant Condition x Science ID x Minority Status three-way interaction on course grade $(B=-6.53, S E=2.68, t(549)=-2.44, p=.015,95 \% \mathrm{CI}=$ [-11.79, -1.27]; Fig. 2). Because we found an effect of the belonging intervention, we first isolated the control group to determine science ID's effect on performance between minority and majority students to address RQ1.

Replicating Study 1 findings, control condition results indicate science ID was more predictive of course performance for minority than for majority students. For control group students, there was a marginal Science ID x Minority Status interaction $(B=3.81, S E=1.94$, $t(549)=1.96, p=.051,95 \% \mathrm{CI}=[-.01,7.63]$; Fig. 2). Science ID was more predictive of minority students' performance $(B=6.02, S E=1.52, t(549)=3.95, p=.001,95 \% \mathrm{CI}=[3.03$, 9.02]) than of majority students' performance $(B=2.22, S E=1.23, t(549)=1.80, p=.072,95 \%$ $\mathrm{CI}=-[.20,4.63])$. For every 1 -unit increase in science ID, minority students scored $6 \%$ higher in the course, whereas majority students scored $2 \%$ higher.

\footnotetext{
12 Though 572 students completed the end-of-semester survey, not all completed belonging and science ID measures; thus, degrees of freedom vary in the analyses. 549 students completed the science ID measure, 461 students completed the belonging measure, and 460 students had all complete demographic, science ID, belonging, and grade measures.
} 


\section{RQ2: Is the differential effect of science ID on performance due to science ID}

conferring an increased sense of belonging? Analyses were consistent with the hypothesis that belonging is an active component that makes science ID particularly important for minority students. The following results support this theory: (a) science ID predicted belonging for minority, not majority, students; (b) the belonging intervention improved belonging for minority, not majority, students; and (c) the belonging intervention's effect mediated the relationship between science ID and course performance.

First, science ID was a significant predictor of belonging for minority but not majority students $(B=.30, S E=.10, t(461)=2.99, p=.003,95 \% \mathrm{CI}=[.10, .50])$. Majority students reported similar belonging regardless of their science ID $(B=.03, S E=.06, t(461)=.46, p=$ $.645,95 \% \mathrm{CI}=[-.10, .15])$. However, sense of belonging for minority students differed by science ID $(B=.33, S E=.08, t(461)=4.19, p<.0001,95 \% \mathrm{CI}=[.18, .49]$; Fig. 3$)$, such that students who reported higher science ID also reported higher belonging.

Second, the social belonging intervention boosted self-reported belonging for minority but not majority students $(B=.39, S E=.15, t(461)=2.51, p=.012,95 \% \mathrm{CI}=[.08, .69])$. Among minority students, receiving the intervention improved sense of belonging $(B=.33, S E=$ $.08, t(461)=4.19, p<.001,95 \% \mathrm{CI}=[.18, .49])$, whereas for majority students, the manipulation did not affect belonging $(B=.03, S E=.06, t(461)=.46, p=.645,95 \% \mathrm{CI}=[-.10$, $.15])$.

As a final step, we put these patterns of results together to explore how the measure of social belonging operated across conditions and subgroups. We conducted a moderated mediation analysis to determine if, and for whom, the measure of social belonging mediated the 
effect of science ID on grade. In other words, is belonging the mechanism through which science ID affects performance? If so, does the effect differ between minority and majority students?

Using the Hayes (2012) PROCESS macro v3.0 to explore patterns of moderated mediation (Model 70), we found that the measure of belonging only mediated the effect of science ID on performance among minority students in the control condition (indirect effect: $B=$ $.92,95 \% \mathrm{CI}=[.14,2.10]$; Fig. 4A). For these students, science ID was positively associated with belonging $(B=.44, S E=.12, t(460)=3.67, p<.001,95 \% \mathrm{CI}=[.21, .68])$, and belonging was positively associated with performance $(B=2.79, S E=1.13, t(460)=2.46, p=.014,95 \% \mathrm{CI}=$ $[.56,5.02])$

However, in line with our hypothesis, the social belonging intervention rendered individual differences in belonging irrelevant in predicting grades, as belonging did not mediate the effect of science ID among minority students who received the intervention (indirect effect: $B$ $=-.56,95 \% \mathrm{CI}=[-2.07, .32])$. Among these students, belonging did not predict class grade $(B=$ $-1.70, S E=1.36, t(460)=-1.25, p=.212,95 \% \mathrm{CI}=[-4.36, .97] ;$ Fig. 4B). Rather, the manipulation boosted social belonging across the sample; thus, individual differences in reported belonging had less predictive power.

These results were supported by the three-way interaction reported previously. Although science ID differentially predicted course performance for majority and minority students in the control condition, no Science ID x Minority Status interaction appeared among students who received the belonging intervention $(B=-2.72, S E=1.86, t(549)=-1.47, p=.143,95 \% \mathrm{CI}=[-$ $6.38, .92])$. Similar to previous findings, majority students in the intervention condition performed better in the course as science ID increased $(B=2.92, S E=1.19, t(549)=2.46, p=$ $.014,95 \% \mathrm{CI}=[.59,5.25]$; Fig. 4D). For every 1 -unit increase in science ID, majority students 
experienced a $3 \%$ boost in grade, similar in magnitude to control condition majority students. However, for minority students who received the intervention, science ID no longer predicted grade $(B=.20, S E=1.44, t(549)=.14, p=.892,95 \% \mathrm{CI}=[-2.63,3.02] ;$ Fig. 4B $)$. This suggests that for minority students, whose belonging are more likely to be threatened, a belonging intervention appears to mimic the effect of having high science ID.

In line with this, simple slopes analysis revealed the belonging intervention differentially affected course performance for minority students with low and high science ID. Those with low science ID significantly benefitted from the belonging intervention $(B=5.25, S E=2.28, t(549)=$ $2.31, p=.021,95 \% \mathrm{CI}=[.78,9.72])$, whereas those with high science ID were not affected $(B=-$ $3.50, S E=2.17, t(549)=-1.61, p=.108,95 \% \mathrm{CI}=[-7.77, .78])$.

Supplemental analyses of course passage. We also analyzed whether the three-way interaction significantly predicted passing the course, an important outcome because the course is the first in a series of STEM courses required for science majors or those pursuing a health career.

Similar to the grade findings, a binary logistic regression analysis revealed a significant three-way interaction on passing $(O R=-1.49, S E=.59, p=.012,95 \% \mathrm{CI}=[-2.65,-.34])$. In the control condition, there was a significant Science ID x Minority Status interaction $(O R=1.01$, $S E=.43, p=.019,95 \% \mathrm{CI}=[.17,1.86] ;$ Fig. 5). For majority students, science ID did not influence the likelihood of passing the course $(O R=.002, S E=.27, p=.993,95 \% \mathrm{CI}=[-.53$, $.54]) ; 84 \%$ of both low and high science ID majority students passed. However, science ID had the predicted effect on passing for minority students $(O R=1.02, S E=.34, p=.003,95 \% \mathrm{CI}=$ $[.36,1.68]) .87 \%$ of high science ID minority students passed, whereas only $60 \%$ of low science ID minority students passed. 
In the belonging condition, however, the Science ID x Minority Status interaction disappeared $(O R=-.48, S E=.40, p=.240,95 \% \mathrm{CI}=[-1.26, .31] ;$ Fig. 5), illustrating how the belonging intervention negated science ID's effect. In the belonging condition, science ID did not affect course passage for either majority students $(O R=.42, S E=.26, p=.111,95 \% \mathrm{CI}=[-$ $.10, .94]$; Fig. 5) or minority students $(O R=-.06, S E=.30, p=.852,95 \%$ CI = [-.64, .54]; Fig. 5). For majority students, $79 \%$ of low science ID and $88 \%$ of high science ID students passed; for minority students, $79 \%$ of low science ID and $77 \%$ of high science ID students passed.

\section{Discussion}

Consistent with Study 1 findings, results from the Study 2 control group found science ID was more predictive of outcomes for minority students than for majority students. This effect, however, was dampened among minority students who received a social belonging intervention, providing support for RQ2, which asked whether belonging served as a psychological mechanism of science ID. After receiving the belonging intervention, minority students, regardless of science ID level, performed similarly to majority students. Importantly, this effect was seen for both course grade and likelihood of passing the course.

These results suggest that science ID is important for minority students because it confers a sense of belonging in science that might otherwise be negatively-targeted due to their marginalized group status. This enhanced belonging then bolsters performance in a difficult, evaluative course. For control students, having a strong science ID led to higher performance, whereas having a weak science ID led to lower performance. This relationship was mediated by science ID's effect on sense of belonging. However, a social belonging exercise eliminated this relationship between science ID and performance, highlighting how an active component of the positive effect of science ID may stem from it communicating belonging. This is especially 
evident in the finding that the social belonging intervention had larger effects on minority students with low science ID, who may doubt their belonging in science.

These results show that enhancing belonging is one way to counteract the threat experienced by stereotyped students with low domain-belonging. It is not that enhancing belonging diminishes the role of science ID; rather, higher belonging serves as a protective barrier against the consequence of having low science ID. This evidence suggests that the social belonging manipulation enhanced belonging similar to having a strong science ID.

\section{General Discussion}

Despite the increasing emphasis on promoting science identification (Falk \& Needham, 2011), few empirical studies have investigated how science ID impacts college students' outcomes. The present research builds on prior literature by demonstrating that 1) science ID differentially impacts majority and minority students, and 2) social belonging serves as a psychological mechanism through which science ID impacts academic performance.

In support of the first claim, results from both studies showed science ID was differentially predictive of course performance, such that the same increase in science ID was related to a greater increase in grade for minority than for majority students. While previous work had shown the importance of science ID for minority students (Chang et al., 2011; Hazari et al., 2013), research had not directly compared whether science ID had differential benefits for them. Data from both studies show that while students with high science ID performed better in the course compared to those with low science ID, the magnitude of this difference was greater within minority students. For minority students, the confluence of having low science ID and being subject to stereotypes undermining sense of belonging (Steele, Spencer, \& Aronson, 2002) 
was particularly harmful. Those with high science ID were relatively protected against these stereotypes (Woodcock, Hernandez, Estrada, \& Schultz, 2012).

After showing science ID differentially impacted majority and minority students, we examined whether this effect operated through the mechanism of bolstering students' sense of belonging. We obtained evidence by both measuring students' sense of belonging and experimentally manipulating it. For the latter, we found evidence that science ID uniquely influenced self-reported belonging among minority and majority students. While majority students across all science ID levels reported similar belonging, minority students with high science ID reported higher belonging than those with low science ID.

Experimentally-manipulated belonging also supported the argument that social belonging is the active ingredient explaining science ID's effect on performance. This effect was reduced to non-significance among minority students who received a belonging intervention, whereas for control condition minority students, belonging still significantly mediated the effect of science ID on course performance. That is, when belonging was established through an intervention, science ID was no longer needed to bolster performance. Though the belonging intervention did not specifically target science belonging, we believe it was able to protect against sciencespecific threat because the intervention was conducted within students' science environment. This, coupled with the fact that the interaction was completed with science peers, may have contributed to the belonging intervention enhancing science belonging.

These findings are particularly important in light of research showing that children early on start developing stereotypes about who can and cannot excel in STEM-oriented fields (Cvencek, Meltzoff, \& Greenwald, 2011). Increasing children's science ID may be beneficial for halting the development of these stereotypes, as the current study suggests that minority 
individuals who develop a strong science ID may be buffered from effects of stereotypes and belonging uncertainty. Indeed, some conceptualizations of 'identity' stipulate that it derives from

group memberships or contexts (Tajfel \& Turner, 1979; Turner, 1975), analogous to belonging to that group or domain. Together with our current findings, this suggests that increasing science identification may be one means of increasing belonging in STEM, and ultimately a step toward equity in science.

\section{Limitations and Future Directions}

One significant limitation is that the present work did not address issues of intersectionality. Indeed, identities are multifaceted, and individuals are simultaneously members of many groups (e.g., gender, racial, socio-economic). The role of each of these identities - and certainly their intersection- is incredibly important and necessitates further research. In the current studies, the primary reason for omission of intersectionality related to a lack of statistical power to make responsible comparisons between intersectional categories (e.g., only 16 students and 21 students in Study 1 and Study 2, respectively, were doubly-stigmatized (first-generation and non-White)). Thus, an important unanswered question is whether science ID differentially impacts such students or, more generally, whether science ID's effect varies as a function of intersectional identities.

Given that this is one of the first studies to empirically examine the psychological mechanisms driving science ID's effect on performance, future work should aim to replicate the findings in other contexts. The present studies were implemented only in Introductory Biology which, at the current university, is comprised of majority Whites and women. Would the same results appear if the intervention was delivered in other science domains with different demographic profiles (see Binning \& Unzueta, 2013; Murphy, Steele, \& Gross, 2007; Walton, 
Logel, Peach, Spencer, \& Zanna, 2015)? Substantial evidence reveals the presence of gender stereotypes in math (Nosek, Banaji, \& Greenwald, 2002; Riegle-Crumb \& King, 2010), where women may be at greater risk for stereotype threat than in the life-sciences. Here, science identity among women may be more important (Vincent-Ruz \& Schunn, 2017).

Future extensions of this work should also examine whether the race and science ID relationship exists at other educational levels (e.g., elementary, middle school). Extensive work has demonstrated that racial/ethnic-minoritized students face barriers to STEM inclusion at every step in their education (Cooper \& Burciaga, 2011), and experiences in science during middle and high school significantly influence whether individuals stay on the STEM pathway in college (Astin \& Sax, 1996). In fact, Obsorne and Walker (2006) found that ethnic-minority students in $9^{\text {th }}$-grade with high levels of school-identification were less likely to drop out after 2 years, compared to ethnic-minority students with low levels of school-identification. Such findings shed light on when science identification or awareness of negative performance stereotypes become salient and affect academic outcomes. As with other social psychological interventions, it is important to recognize that these findings do not place the burden of change on the student. Rather, they should inform ways that institutions create situations and environments that consider and support all students. These findings suggest that institutional actions that consider students' psychological experiences can lead to meaningful improvements, and further reinforce the notion that institutions should shoulder the effort to create equitable academic environments.

One methodological limitation of the present studies, science ID was measured at different times over the semester and seemed to not affect results. However, it is possible that science ID may fluctuate over time as students calibrate their initial identities with respect to their actual outcomes. Although previous research (Carlone \& Johnson, 2007; Elmesky \& Seiler, 
2007) and the similarity of results between both studies suggest science ID is relatively stable, future work could aim to measure science ID repeatedly to understand its potential time course and relationship to success and adversity in science.

Finally, we note that Study 1 included a values affirmation manipulation that did not moderate the present findings. This is notable, given previously-seen connections between affirmation and belonging (Shnabel et al., 2013). However, as is often true of null findings, it is difficult to know if features of the present methods limited the effects of affirmation. For example, the affirmation was delivered later in the term, before the $2^{\text {nd }}$ or $4^{\text {th }}$ exam but after students had already experienced several weeks in the course. Given the importance of timing and early delivery for affirmation effects (e.g., Cohen \& Sherman, 2014), this may have simply been too late for a single, light-touch affirmation to have an effect.

\section{Conclusion}

Although the number of students entering science is generally increasing, disparities across major social categories persist. The present research suggests an optimistic note for promoting a specific identity to address these disparities. Science identity - a sense that one is a "science person" - consistently had positive associations with performance in a gateway science course. This was particularly true for minority students, in part because science ID bolstered sense of belonging in the course and college more generally. Helping students develop and maintain a stable sense of science identification may be a promising and effective way to help them contend with the threat of being stereotyped and marginalized in STEM. 


\section{Table 1}

Study 1 and Study 2 demographics

\begin{tabular}{lcc}
\hline & Study $1(N=368)$ & Study $2(N=572)$ \\
Variable & $\%$ & $\%$ \\
\hline Women & 70.92 & 75.00 \\
First-Generation & 12.77 & 14.16 \\
White & 66.85 & 75.52 \\
Black/African-American & 7.34 & 6.29 \\
Asian/Asian-American & 22.28 & 31.47 \\
Hispanic/Latino/a & 3.53 & 2.62 \\
Native American/American Indian & 0.00 & 0.00 \\
Other & 2.17 & 7.69 \\
& & 57.52 \\
Majority: White, continuing-generation & 58.70 & 42.48 \\
Minority: Non-White and/or first-generation & 41.30 & \\
\hline
\end{tabular}


Table 2

Correlations between variables of interest for Study 1

\begin{tabular}{l|ccccc}
\hline \multicolumn{1}{l}{ 1. Instructor } & 1 & 2 & 3 & 4 & 5 \\
2. Minority Status & 1 & & & & \\
3. Condition & .05 & 1 & & & \\
4. Science ID & .00 & -.01 & 1 & & \\
5. Class Grade & -.00 & -.05 & .04 & 1 & \\
\hline$* p<.05$. & -.06 & -.10 & .02 & $.42 *$ & 1 \\
\end{tabular}

Table 3

Correlations between variables of interest for Study 2

\begin{tabular}{l|cccccc}
\hline \multicolumn{1}{l}{} & 1 & 2 & 3 & 4 & 5 & 6 \\
\hline 1. Semester & 1 & & & & \\
2. Minority Status & -.01 & 1 & & & & \\
3. Condition & .02 & -.04 & 1 & & & \\
4. Belonging & -.04 & -.09 & -.01 & 1 & & \\
5. Science ID & $-.14 *$ & .06 & -.02 & $.15^{*}$ & 1 & \\
6. Class Grade & .00 & -.08 & .04 & $.22^{*}$ & .19 & 1 \\
\hline$* p<.05$.
\end{tabular}




\section{Figure 1}

Study 1: Effect of Science ID $( \pm I S D)$ and Minority Status on Course Grade

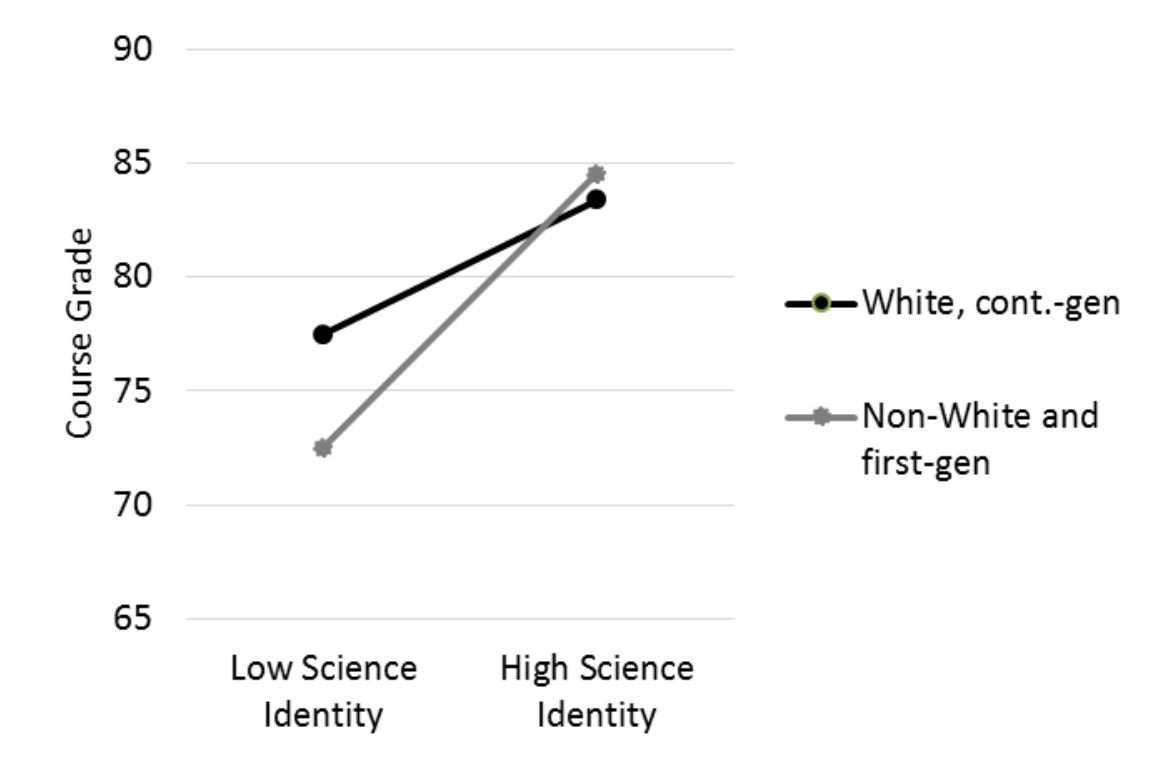

Note. Errors bars represent standard error of the mean. 


\section{Figure 2}

Study 2: Effect of Science ID $( \pm 1$ SD) and Minority Status on Course Grade for Control and Belonging Condition Participants

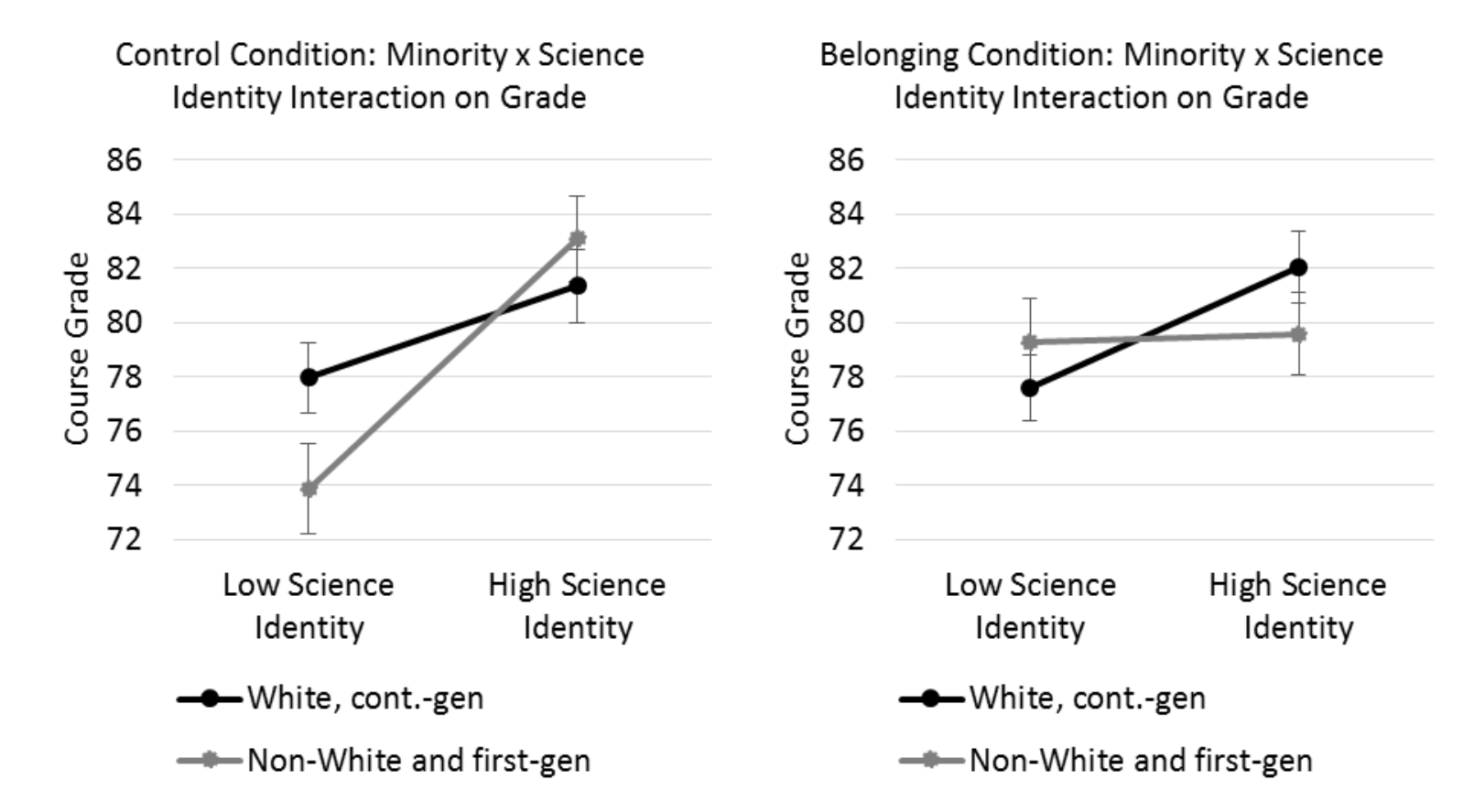

Note. Errors bars represent standard error of the mean. 


\section{Figure 3}

Study 2: Effect of Science ID ( \pm 1 SD) and Minority Status on Reported Belonging

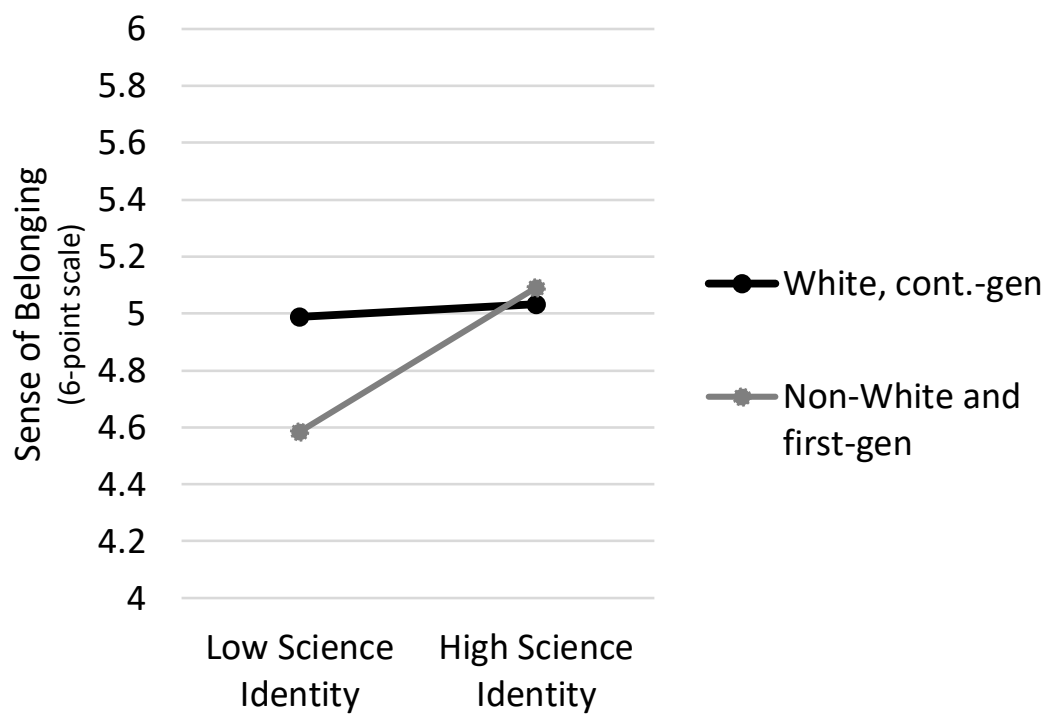

Note. Errors bars represent standard error of the mean. 


\section{Figure 4}

Study 2: Moderated Mediation Model
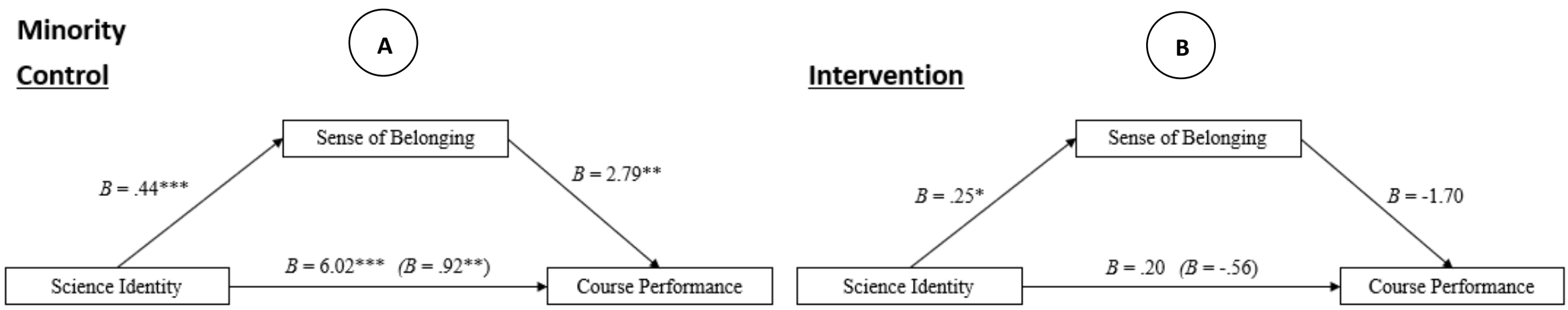

\section{Majority \\ Control}
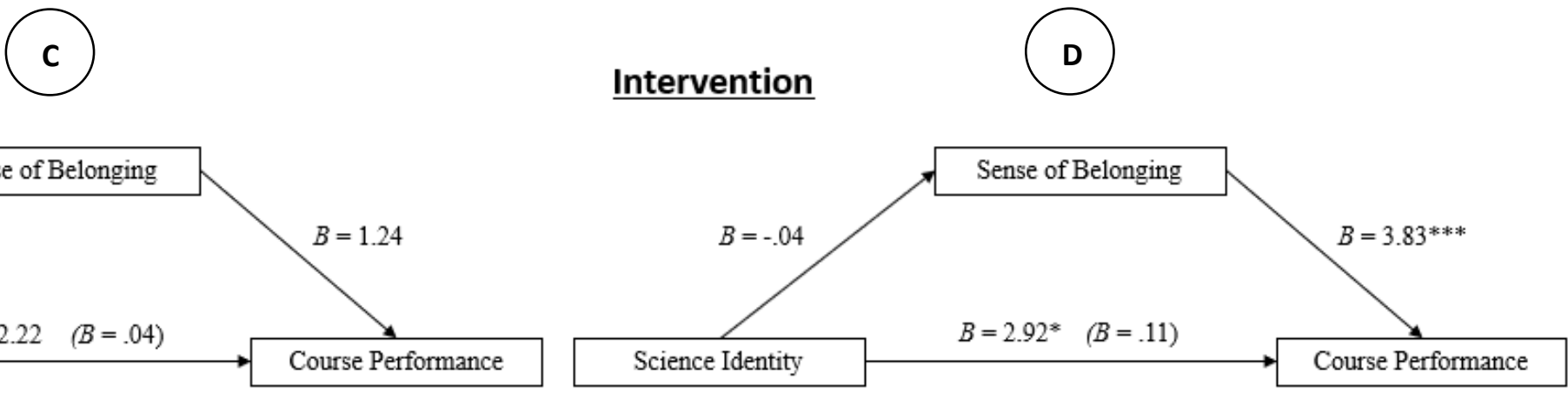

Science Identity

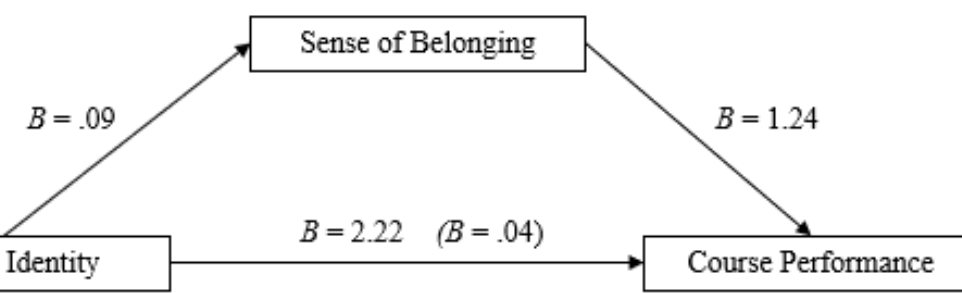

Notes. Reported sense of belonging mediating the relationship between science ID and course performance, moderated by minority status and intervention condition. Indirect effects of science ID on course performance, controlling for reported sense of belonging, in parentheses.

$* p<.05, * * p<.01, * * * p<.00$ 


\section{Figure 5}

Study 2: Effect of Science ID (+/-1 SD) and Minority Status on Course Passage

Notes. Passing the course denoted as earning a $\mathrm{C}$ or higher.
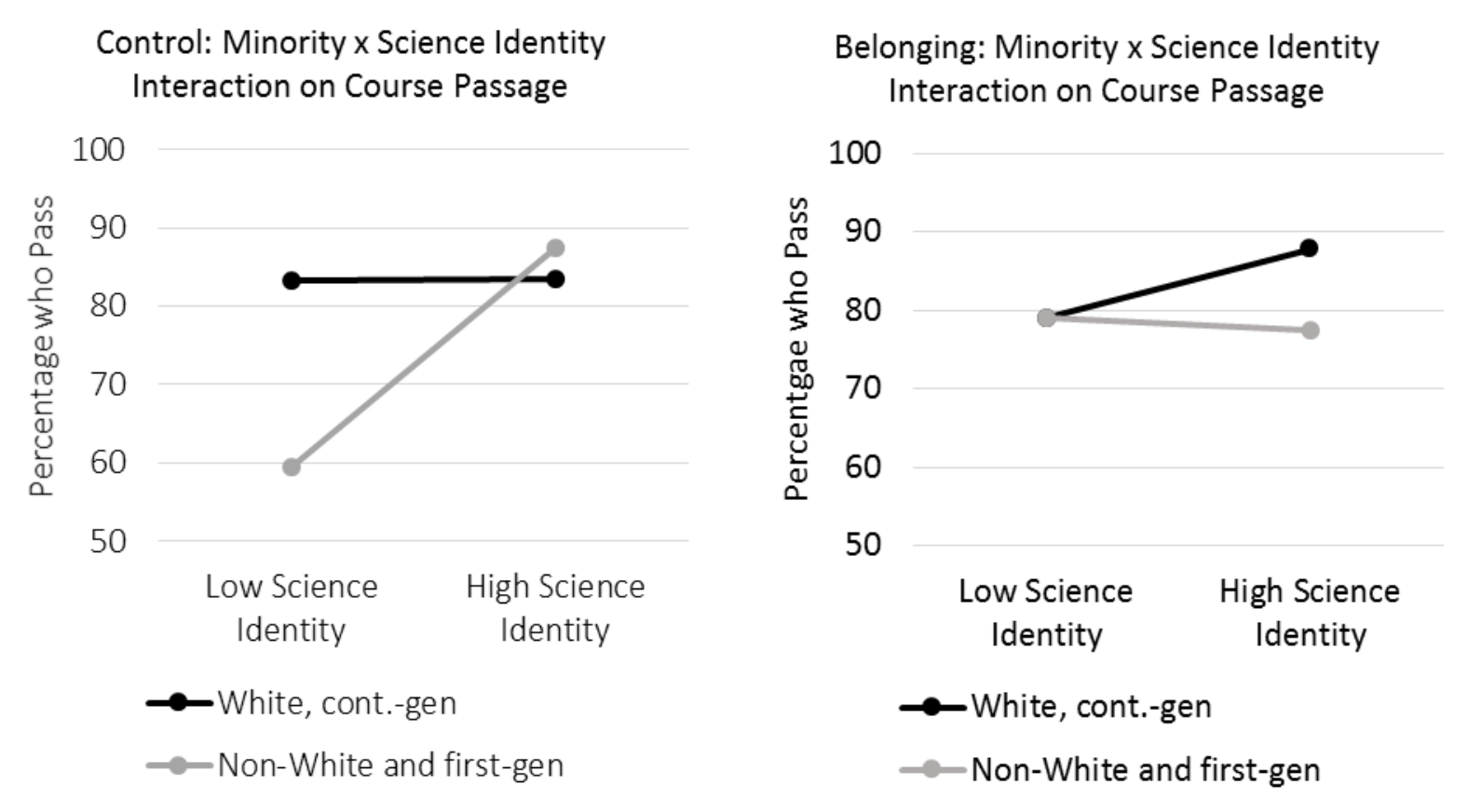


\section{References}

Aschbacher, P. R., Li, E., \& Roth, E. J. (2010). Is science me? High school students' identities, participation and aspirations in science, engineering, and medicine. Journal of Research in Science Teaching: The Official Journal of the National Association for Research in Science Teaching, 47(5), 564-582.

Astin, A. W. (1993). What matters in college? Four critical years revisited. San Francisco: Jossey-Bass.

Astin, H. S., \& Sax, L. J. (1996). Developing scientific talent in undergraduate women. The equity equation: Fostering the advancement of women in the sciences, mathematics, and engineering, 96-121.

Baron, R. M., \& Kenny, D. A. (1986). The moderator-mediator variable distinction in social psychological research: Conceptual, strategic, and statistical considerations. Journal of Personality and Social Psychology, 51, 1173-1182.

Betancur, L., Rottman, B. M., Votruba-Drzal, E., \& Schunn, C. (2019) Analytical assessment of course sequencing: The case of methodological courses in psychology. Journal of Educational Psychology.

Binning, K. R., \& Browman, A. S. (2020). Theoretical, ethical, and policy considerations for conducting social-psychological interventions to close educational achievement gaps. Social Issues and Policy Review, 14, 182-216.

Binning, K. R., Cook, J. E., Purdie-Greenaway, V., Garcia, J., Chen, S., Apfel, N., Sherman, D. K., \& Cohen, G. L. (2019). Bolstering trust and reducing discipline incidents at a diverse middle school: How self-affirmation affects behavioral conduct during the transition to adolescence. Journal of School Psychology, 75, 74-88. 
Binning, K.R., Kaufmann, N., McGreevy, E.M., Fotuhi, O., Chen, S., Kalender, Z. Y., Marshman, E., Limeri, L.B., Betancur, L., \& Singh, C. (2020). Changing social contexts to foster equity in college STEM classrooms: An ecological belonging intervention. Psychological Science.

Binning, K. R., \& Sherman, D. K. (2011). Categorization and communication in the face of prejudice: When describing perceptions changes what is perceived. Journal of Personality and Social Psychology, 101, 321-336.

Binning, K. R., \& Unzueta, M. M. (2013). Perceiving ethnic diversity on campus: Group differences in attention to hierarchical representation. Social Psychological and Personality Science, 4, 500-507.

Carlone, H. B. (2004). The cultural production of science in reform-based physics: Girls' access, participation, and resistance. Journal of Research in Science Teaching, 41(4), 392-414.

Carlone, H. B., \& Johnson, A. (2007). Understanding the science experiences of successful women of color: Science identity as an analytic lens. Journal of Research in Science Teaching, 44, 1187-1218.

Chang, M. J., Eagan, M. K., Lin, M. H., \& Hurtado, S. (2011). Considering the impact of racial stigmas and science identity: Persistence among biomedical and behavioral science aspirants. The Journal of higher education, 82(5), 564-596.

Chemers, M. M., Zurbriggen, E. L., Syed, M., Goza, B. K., \& Bearman, S. (2011). The role of efficacy and identity in science career commitment among underrepresented minority students. Journal of Social Issues, 67(3), 469-491.

Cheryan, S., \& Bodenhausen, G. V. (2011). Model Minority. In S. M. Caliendo, \& C. D. McIlwain (eds.)., Routledge Companion to Race \& Ethnicity (pp. 173-176). Routledge. 
Cheryan, S., Ziegler, S. A., Montoya, A. K., \& Jiang, L. (2017). Why are some STEM fields more gender balanced than others?. Psychological Bulletin, 143(1), 1-35.

Cohen, G. L., Garcia, J., Purdie-Vaughns, V., Apfel, N., \& Brzustoski, P. (2009). Recursive processes in self-affirmation: Intervening to close the minority achievement gap. Science, 324(5925), 400-403.

Cooper, C. R., \& Burciaga, R. (2011). Pathways to college, to the professoriate, and to a green card: Linking research, policy, and practice on immigrant Latino youth. Migration in the 21st century: Rights, outcomes, and policy, 177-191.

Crocker, J., \& Major, B. (1989). Social stigma and self-esteem: The self-protective properties of stigma. Psychological Review, 96(4), 608-630.

Croizet, J. C., \& Claire, T. (1998). Extending the concept of stereotype threat to social class: The intellectual underperformance of students from low socioeconomic backgrounds. Personality and Social Psychology Bulletin, 24(6), 588-594.

Cvencek, D., Meltzoff, A. N., \& Greenwald, A. G. (2011). Math-gender stereotypes in elementary school children. Child development, 82(3), 766-779.

Dasgupta, N. (2011). Ingroup experts and peers as social vaccines who inoculate the selfconcept: The stereotype inoculation model. Psychological Inquiry, 22(4), 231-246.

Dawson, E. (2014). "Not designed for us": How science museums and science centers socially exclude low-income, minority ethnic groups. Science education, 98(6), 981-1008.

Dweck, C. S. (2008). Can personality be changed? The role of beliefs in personality and change. Current directions in psychological science, 17(6), 391-394.

Eccles, J. S., \& Barber, B. L. (1999). Student council, volunteering, basketball, or marching band: What kind of extracurricular involvement matters?. Journal of Adolescent 
Research, 14(1), 10-43.

Elmesky, R., \& Seiler, G. (2007). Movement expressiveness, solidarity and the (re) shaping of African American students' scientific identities. Cultural Studies of Science Education, 2(1), 73-103.

Falk, J. H., \& Needham, M. D. (2011). Measuring the impact of a science center on its community. Journal of Research in Science Teaching, 48(1), 1-12.

Freeman, T. M., Anderman, L. H., \& Jensen, J. M. (2007). Sense of belonging in college freshmen at the classroom and campus levels. The Journal of Experimental Education, 75(3), 203-220.

Gee, J. P. (2000). Chapter 3: Identity as an analytic lens for research in education. Review of research in education, 25(1), 99-125.

Hayes, A. F. (2012). PROCESS: A versatile computational tool for observed variable mediation, moderation, and conditional process modeling.

Hazari, Z., Sadler, P. M., \& Sonnert, G. (2013). The science identity of college students: Exploring the intersection of gender, race, and ethnicity. Journal of College Science Teaching, 42(5), 82-91.

Hazari, Z., Sonnert, G., Sadler, P. M., \& Shanahan, M. C. (2010). Connecting high school physics experiences, outcome expectations, physics identity, and physics career choice: A gender study. Journal of Research in Science Teaching, 47(8), 978-1003.

Hulleman, C. S., \& Harackiewicz, J. M. (2009). Promoting interest and performance in high school science classes. Science, 326(5958), 1410-1412.

Hulleman, C. S., Kosovich, J. J., Barron, K. E., \& Daniel, D. B. (2017). Making connections: 
Replicating and extending the utility value intervention in the classroom. Journal of Educational Psychology, 109(3), 387-404.

Irwin, J. R., \& McClelland, G. H. (2001). Misleading heuristics and moderated multiple regression models. Journal of Marketing Research, 38(1), 100-109.

Leinhardt, G., Crowley, K., \& Knutson, K. (Eds.). (2003). Learning conversations in museums. Taylor \& Francis.

Leslie, S. J., Cimpian, A., Meyer, M., \& Freeland, E. (2015). Expectations of brilliance underlie gender distributions across academic disciplines. Science, 347(6219), 262-265.

MacKinnon, D. P., \& Pirlott, A. G. (2015). Statistical approaches for enhancing causal interpretation of the M to Y relation in mediation analysis. Personality and Social Psychology Review, 19(1), 30-43.

Meyer, M., Cimpian, A., \& Leslie, S. J. (2015). Women are underrepresented in fields where success is believed to require brilliance. Frontiers in Psychology, 6, 235-245.

Miyake, A., Kost-Smith, L. E., Finkelstein, N. D., Pollock, S. J., Cohen, G. L., \& Ito, T. A. (2010). Reducing the gender achievement gap in college science: A classroom study of values affirmation. Science, 330(6008), 1234-1237.

Murphy, M. C., Steele, C. M., \& Gross, J. J. (2007). Signaling threat: How situational cues affect women in math, science, and engineering settings. Psychological Science, 18(10), 879885.

National Center for Education Statistics. (2014). Number and percentage distribution of science, technology, engineering, and mathematics (STEM) degrees/certificates (NCES Table 318.45). Retrieved June 20, 2018, from https://nces.ed.gov/programs/digest/d17/tables/dt17_318.45.asp?current=yes. 
Nosek, B. A., Banaji, M. R., \& Greenwald, A. G. (2002). Harvesting implicit group attitudes and beliefs from a demonstration web site. Group Dynamics: Theory, Research, and Practice, 6(1), 101-115.

Osborne, J. W., \& Walker, C. (2006). Stereotype threat, identification with academics, and withdrawal from school: Why the most successful students of colour might be most likely to withdraw. Educational Psychology, 26(4), 563-577.

Pascarella, E. T., Pierson, C. T., Wolniak, G. C., \& Terenzini, P. T. (2004). First-generation college students: Additional evidence on college experiences and outcomes. The Journal of Higher Education, 75(3), 249-284.

Ramsey, L. R., Betz, D. E., \& Sekaquaptewa, D. (2013). The effects of an academic environment intervention on science identification among women in STEM. Social Psychology of Education, 16(3), 377-397.

Riegle-Crumb, C., \& King, B. (2010). Questioning a white male advantage in STEM: Examining disparities in college major by gender and race/ethnicity. Educational Researcher, 39(9), 656-664.

Seymour, E., Hewitt, N. M., \& Friend, C. M. (1997). Talking about leaving: Why undergraduates leave the sciences (Vol. 12). Boulder, CO: Westview Press.

Sherman, D. K., Hartson, K. A., Binning, K. R., Purdie-Vaughns, V., Garcia, J., Taborsky-Barba, S., Tomasetti, S., Nussbaum, A. D., \& Cohen, G. L. (2013). Deflecting the trajectory and changing the narrative: how self-affirmation affects academic performance and motivation under identity threat. Journal of Personality and Social Psychology, 104, $591-618$.

Shnabel, N., Purdie-Vaughns, V., Cook, J. E., Garcia, J., \& Cohen, G. L. (2013). Demystifying 
values-affirmation interventions: Writing about social belonging is a key to buffering against identity threat. Personality and Social Psychology Bulletin, 39(5), 663-676.

Sirin, S. R. (2005). Socioeconomic status and academic achievement: A meta-analytic review of research. Review of educational research, 75(3), 417-453.

Steele, C. M. (1997). A Threat in the air: How stereotypes shape intellectual identity and performance. American Psychologist, 52(6), 613-629.

Steele, C. M., \& Aronson, J. (1995). Stereotype threat and the intellectual test performance of African Americans. Journal of Personality and Social Psychology, 69, 797-811.

Steele, C. M., Spencer, S. J., \& Aronson, J. (2002). Contending with group image: The psychology of stereotype and social identity threat. In Advances in experimental social psychology (Vol. 34, pp. 379-440). Academic Press.

Stephens, N. M., Fryberg, S. A., Markus, H. R., Johnson, C. S., \& Covarrubias, R. (2012). Unseen disadvantage: How American universities' focus on independence undermines the academic performance of first-generation college students. Journal of Personality and Social Psychology, 102(6), 1178-1197.

Stets, J. E., Brenner, P. S., Burke, P. J., \& Serpe, R. T. (2017). The science identity and entering a science occupation. Social science research, 64, 1-14.

Stout, J. G., Dasgupta, N., Hunsinger, M., \& McManus, M. A. (2011). STEMing the tide: using ingroup experts to inoculate women's self-concept in science, technology, engineering, and mathematics (STEM). Journal of Personality and Social Psychology, 100, 255-270.

Tajfel, H., \& Turner, J. C. (1979). An integrative theory of intergroup conflict. In W. G. Austin \& S. Worchel (Eds.), The social psychology of intergroup relations (pp. 33-47). Monterey, CA: Brooks/Cole. 
Tibbetts, Y., Harackiewicz, J. M., Canning, E. A., Boston, J. S., Priniski, S. J., \& Hyde, J. S. (2016). Affirming independence: Exploring mechanisms underlying a values affirmation intervention for first-generation students. Journal of Personality and Social Psychology, 110(5), 635-659.

Turner, J. C. (1975). Social comparison and social identity: Some prospects for intergroup behaviour. European Journal of Social Psychology, 5(1), 1-34.

Verdín, D., \& Godwin, A. (2015). First in the family: A comparison of first-generation and nonfirst-generation engineering college students. Frontiers in Education Conference (FIE), 1-8.

Vincent-Ruz, P., \& Schunn, C. D. (2017). The increasingly important role of science competency beliefs for science learning in girls. Journal of Research in Science Teaching, 54, 790822.

Vincent-Ruz, P., \& Schunn, C. D. (2018). The nature of science identity and its role as the driver of student choices. International Journal of STEM Education, 5, 48-60.

Walton, G. M. \& Brady, S. T. (2020). To appear in G. M. Walton \& A. J. Crum (Eds.) Handbook of Wise Interventions, Guilford Press: New York.

Walton, G. M., \& Cohen, G. L. (2007). A question of belonging: race, social fit, and achievement. Journal of Personality and Social Psychology, 92(1), 82-96.

Walton, G. M., \& Cohen, G. L. (2011). A brief social-belonging intervention improves academic and health outcomes of minority students. Science, 331(6023), 1447-1451.

Walton, G. M., Logel, C., Peach, J. M., Spencer, S. J., \& Zanna, M. P. (2015). Two brief interventions to mitigate a "chilly climate" transform women's experience, relationships, and achievement in engineering. Journal of Educational Psychology, 107(2), 468. 
Walton, G. M., \& Wilson, T. D. (2018). Wise interventions: Psychological remedies for social and personal problems. Psychological Review, 125(5), 617-672.

Weiner, B. (1985). An attributional theory of achievement motivation and e emotion. Psychological Review, 92(4), 548-573.

Wilson, T. D., \& Linville, P. W. (1982). Improving the academic performance of college freshmen: Attribution therapy revisited. Journal of Personality and Social Psychology, 42(2), 367-376.

Woodcock, A., Hernandez, P. R., Estrada, M., \& Schultz, P. (2012). The consequences of chronic stereotype threat: Domain disidentification and abandonment. Journal of personality and social psychology, 103(4), 635-659.

Yeager, D. S., \& Walton, G. M. (2011). Social-psychological interventions in education: They're not magic. Review of educational Research, 81(2), 267-301.

Yeager, D. S., Walton, G. M., Brady, S. T., Akcinar, E. N., Paunesku, D., Keane, L., ... \& Gomez, E. M. (2016). Teaching a lay theory before college narrows achievement gaps at scale. Proceedings of the National Academy of Sciences, 113-121. 